\title{
Librarians Skills and Competencies for Scholarly Communication and Repository Management in Nigeria
}

\author{
Usman Ahmed Adam ${ }^{1}$, Kiran Kaur ${ }^{2}$ \\ ${ }^{1,2}$ Department of Library and Information Science, Faculty of Computer Science and Information Technology \\ University of Malaya, Malaysia \\ ${ }^{1}$ University Library, Kaduna State University, Nigeria \\ E-mail: ${ }^{1}$ usadams@kasu.edu.ng, ${ }^{2}$ kiran@um.edu.my
}

Article History: Received: 10 November 2020; Revised: 12 January 2021; Accepted: 27 January 2021; Published online: 05 April 2021

\begin{abstract}
The rapid change in scholarly communication and knowledge management has transformed the repository services and imposed new skills and competencies for repository management. This study is posed to assess the skills and competencies of librarians for repository management and scholarly communication in academic institutions in Nigeria. The study adopted a survey research design to assess the skills and competencies of the librarians using NASIG "Core Competencies for Scholarly Communication Librarians 2017". The sample size of the study comprises 120 librarians across 40 institutions. The findings of the study indicate among others that; $74 \%$ of the librarians have a general understanding of repository platforms, $54.17 \%$ background knowledge of open access movement, and $58 \%$ experience in advocacy for open access. At the same time, $83.3 \%$ of the librarians can capture, store, and preserve the research output. While $62.3 \%$ understand research impact, only 35.8\% understand emerging alternatives measures of the impact. Although, $73.1 \%$ understand Data description and storage, only $20.8 \%$ understand text and data mining. The study concluded that awareness, skills, and competencies of the librarians is increasing and recommends among others; setting up a framework for the employment of repository and scholarly communication librarians and training on repository management and scholarly communication.
\end{abstract}

Keywords: Repository management, skills and competencies, Scholarly communication, Librarians in Nigeria.

\section{Introduction}

Not only meant for underpinning and legitimizing new trend of scholarly communication but shifting the economic burden of scholarly publishing (Lynch, 2003). Institutional repository is a strategy devised by open access movement to facilitate the widespread implementation of open access across research institutions globally. With the advancement in information and communication technology, the institutional repository becomes an essential infrastructure for knowledge sharing in the global research community (Saha, Sharma, \& Meichieo, 2008). From the beginning, institutional repository revolutionized the publication process in the scholarly community, making research findings more visible and accessible in an affordable and financial convenience manner. Therefore, it becomes an indispensable avenue for scholarly communication in the global research community (Marsh, 2015). Based on the success being recorded by open access movement, Bergman (2006) forecasted that open access journal and digital repositories will continue to coincide with commercial journals as real means of scholarly communication in the foreseeable future (ImeldawatyGultom, et al, 2020). The role of the institutional repository in emerging scholarly communication cannot be overemphasized. Sanjeeva and Powdwal (2018) considered institutional repository as a cornerstone for scholarly communication activities in the library. Adam \& Kiran (2019) described institutional repository as a "new paradigm in scholarly communication that increases the visibility and adds more prestige to the institutions as well as curtail the barriers of access to scholarly information". This paper is set up to investigate librarians' skills and competencies for scholarly communication and repository management in Nigeria.

It has earlier been described by the "Association of College and Research Libraries" (ACRL) that, scholarly communication is a system that involved the creation, evaluation, and distribution of research and other scholarly works to the global research community as well as its preservation for future use (Lynden, 2002). As scholarly communication becomes more sophisticated and complex, the management of institutional repository requires more "skills and competences" in return. For libraries to effectively support the scholarly communication in this era, librarians need to acquire certain prerequisite skills and competencies. 


\section{North american serials interest group (nasig) "core competencies for scholarly communication".}

As an independent organization saddled with the responsibility of transforming the management of information resources, NASIG was formed to smoothen and enhance the dissemination, acquisition and sustain access to all forms of information resources.

In a bid to harmonize complete areas of prerequisite skills and competencies for scholarly communication librarian (SCL), NASIG developed a framework that identified essential skills and competencies for SCL giving emphasis to "institutional repository management", "publishing services", "copyright services", "data management services" and "assessment and impact metrics". The framework was developed out of investigation and deliberations led by NASIG "Scholarly Communication Core Competencies Task Force". The framework was found worthy of consideration in this study because it incorporates all the areas identified in the competencies for scholarly communication, open-access competencies profile for research data management (Wesolek et al., 2017).

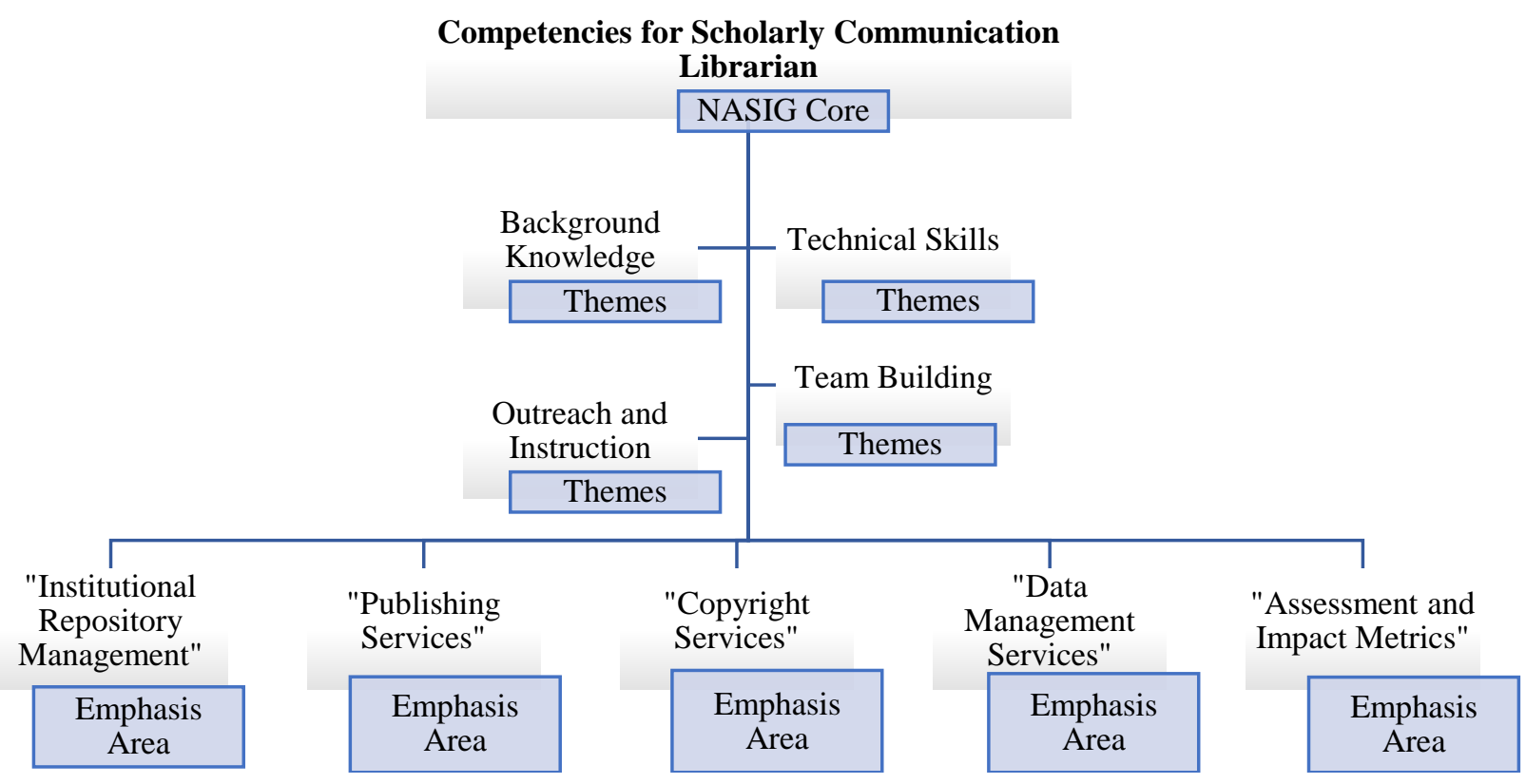

Figure 1. NASIG Framework for Scholarly Communication Librarians

The skills are categorized into general themes and emphasis areas (See appendix A for details).

\section{Literature Review}

It is not the first time to acknowledge the role of institutional repository in transforming scholarly communication. In the first broad-based international study on the rapid evolvement of the infrastructure in scholarship and scholarly communication, Van Westrienen and Lynch (2005) stated that scholarly communication has tremendously enhanced within a very short time, thanks to the creation of institutional repository. Their study ushered literature with a comprehensive report of the status of institutional repositories in Australia, Canada, USA, and ten European countries. Since then, the literature on institutional repository and scholarly communication continues to grow, result of which has change the landscape of scholarly communication from the exploitative control system of commercial publishing to a collaborative participatory approach of open access, making institutional repository a permanent and important part of scholarly communication (Swan, 2005).

As research on institutional repository management grow and become complex, the literature addressing different areas of prerequisite skills and competencies for scholarly communication keeps growing too. NematiAnaraki and Tavassoli-Farahi (2018) proposed a conceptual model for scholarly communication through institutional repositories to facilitate and simplify the creation and management of the repository by experts and librarians. Chawner and Oliver (2013) and Hussain et al., (2017) Showed that customer care service, technical support, and good communication skills are among the competencies needed along with traditional library skills for scholarly librarians in New Zealand. Zhong and Jiang (2016) reported a lack of IT skills and call all for 
personnel training on the development of the institutional repository in China. Gbaje, Yani, and Odigie (2017) identified lack of technical skills of management of institutional repositories among librarians in Nigeria. Equally, Oguche (2018) identified insufficient skills and competencies for management of the repository among the challenges of the practice of institutional repositories in Nigeria. Similarly, Adam and Kiran (2019)and Hussain et al,. (2017b) showed that there is inadequate knowledge and skills in developing standard interface and providing effective user information needs for achieving the best practice of institutional repository in Nigeria. lack of chances for in-depth training deprived librarians to gain new competencies and re-tool themselves with skills to meet the current demands (Rodriguez, 2015).

Based on the needs for identification of skills and competencies for scholarly communication librarian, NASIG developed a framework that includes core competencies of scholarly communication librarians 2017, to guide librarians on the areas of the prerequisite skills and competencies to meet the current demands of scholarly communication (Wesolek et al.,2017).

\section{Methodology}

The study adopted a survey research design to assess the skills and competencies of the librarians in Nigeria using NASIG Core Competencies for "scholarly communication "Librarians 2017. The sample size of the study comprises 120 academic librarians. Purposive sampling techniques was used in selecting 3 librarians working as repository's managers, e-librarians, reference librarians and scholarly communication related positions across 40 institutions in Nigeria. Online survey was developed using the core competencies identified by NASIG, 2017. The survey was administered the respondents using their personal emails, and WhatsApp accounts. The data was collected between March - August 2019.

\section{Findings and Discussion}

Out of the 120 respondents, $29.17 \%$ were female, $70.83 \%$ were male working as librarians at the repository and scholarly communicationrelated positions in across 40 institutions in Nigeria. On the other hand, $60 \%$ of the respondents have master's degrees as their highest qualification while $25 \%$ have bachelor's degree, $9 \%$ have Ph.D. 3.6\% and $4.8 \%$ have Diploma and certificate as their highest qualification respectively.

With regards to background knowledge, the result on table 2 shows that $65 \%$ of respondents understand digital preservation and copyright, and $54.17 \%$ are knowledgeable about open access movement and its impact on scholarly communication.

Table 1.Respondents Demographic Information

\begin{tabular}{|c|c|c|c|}
\hline Category & Items & No. of response & Percentage $\%$ \\
\hline \multirow[t]{2}{*}{ Gender } & Male & 85 & 70.8 \\
\hline & Female & 35 & 29.17 \\
\hline \multicolumn{2}{|l|}{ Total } & 120 & 100 \\
\hline \multirow[t]{5}{*}{ Highest Qualification } & $\mathrm{PhD}$ & 11 & 9 \\
\hline & Master's degree & 72 & 60 \\
\hline & Bachelor's degree & 30 & 25 \\
\hline & Diploma & 3 & 3.6 \\
\hline & Certificate & 4 & 4.8 \\
\hline \multicolumn{2}{|l|}{ Total } & 120 & 100 \\
\hline
\end{tabular}

While $40 \%$ have experience in development and implementation of institutional open access policies, only $25.8 \%$ and $22.5 \%$ are familiar with metadata schema and standards, and legislative environment. This finding is in agreement with Gbaje et al. (2017), that majority of librarians in Nigeria have background knowledge on commercial, open accesspublishing platforms, open access policies and copyright.

On technical skills, it can be observed that, majority of the respondents (74\%) have experience on repository platform. While, half $(50 \%)$ of them have skills on data management solution, only $20 \%$ have expertise on digital object types and format, OPAC, e- classification and cataloging process. Despite having low responses on faculty profiling systems, digital collections and it's technical aspect, the findings corroborate with Okeji, Eze, and Chibueze (2019) on the experience in repository platforms, that librarians understand and use "repository platforms" for arching their publications in Nigeria. 
Similarly, the result also shows that, librarians have experience on outreach and instruction as $58 \%$ of the respondents declared having experience in advocacy for open access, andinstruction in areas of scholarly communication literacy for both faculty members and students, $64 \%$, indicated having experience in educating individuals on effective ways to navigate, evaluate, and contributing to the scholarly conversation.In spite of having significant number of respondents $(76.6 \%, 54 \% \& 51.6 \%)$ with experience in direct supervision of staffs to effectively carry out their assigned duties, managing projects to leverage on the expertise of other librarians and scholars, and building cross-departmental teams respectively, only $15 \%$ of the respondnets can Liaise with faculties on collection development and instruction in area of scholarly communication.

In the area of publishing services (Table 3), it can be observed that, $58.3 \%$ and $56.6 \%$ of the respondents have the ability to collect and disseminate assessment metrics and ability to provide technical support on publishing services. Similarly, 44.4\%, 33.3\%, 21.6\%, and 15\% possessbasic knowledge of relevant metadata schemata, have experience in the full life cycle of publishing, and ability to perform system administration and programming, andexperience of minting identifiers respectively.

Table 2.General Theme

\begin{tabular}{|c|c|c|c|c|c|c|c|}
\hline $\begin{array}{l}\text { Background } \\
\text { Knowledge }\end{array}$ & $\mathbf{R F}$ & $\begin{array}{l}\text { Technical } \\
\text { Skills }\end{array}$ & $\mathbf{R F}$ & $\begin{array}{l}\text { Outreach and } \\
\text { Instruction }\end{array}$ & RF & Team Building & $\mathbf{R F}$ \\
\hline $\begin{array}{l}\text { "Open Access } \\
\text { movement \& its } \\
\text { impact on the } \\
\text { scholarly } \\
\text { publishing } \\
\text { landscape" }\end{array}$ & 65 & $\begin{array}{l}\text { "Repository } \\
\text { platforms" }\end{array}$ & 89 & $\begin{array}{l}\text { "Advocates for Open } \\
\text { Access, including } \\
\text { author's rights, open } \\
\text { access to research, } \\
\text { data, \& Open, } \\
\text { Educational Resources" }\end{array}$ & 70 & $\begin{array}{l}\text { "Building cross- } \\
\text { departmental teams" }\end{array}$ & 62 \\
\hline $\begin{array}{l}\text { "Digital } \\
\text { preservation", }\end{array}$ & 78 & $\begin{array}{l}\text { "Data } \\
\text { management } \\
\text { solutions" }\end{array}$ & 60 & $\begin{array}{l}\text { "Keeping with the } \\
\text { ACRL Framework" for } \\
\text { Information Literacy for } \\
\text { Higher Education" }\end{array}$ & 36 & $\begin{array}{l}\text { "Managing projects to } \\
\text { leverage the expertise } \\
\text { of other librarians \& } \\
\text { researchers" }\end{array}$ & 45 \\
\hline $\begin{array}{l}\text { "Metadata } \\
\text { schemata } \\
\text { standards", }\end{array}$ & 31 & $\begin{array}{l}\text { "Publishing } \\
\text { platforms" }\end{array}$ & 51 & $\begin{array}{l}\text { "Educating individuals } \\
\text { on effective ways to } \\
\text { navigate, evaluate, \& } \\
\text { contributing to the } \\
\text { scholarly conversation" }\end{array}$ & 77 & $\begin{array}{l}\text { "Direct supervision of } \\
\text { employees } \\
\text { effectively carry out } \\
\text { assigned duties" }\end{array}$ & 92 \\
\hline "Copyright" & 65 & $\begin{array}{l}\text { "Faculty } \\
\text { profiling } \\
\text { systems and } \\
\text { their } \\
\text { interrelations } \\
\text { hip" }\end{array}$ & 29 & $\begin{array}{l}\text { "Instruction in areas of } \\
\text { scholarly } \\
\text { communication literacy } \\
\text { for both faculty \& } \\
\text { students", }\end{array}$ & 70 & $\begin{array}{l}\text { "Instruction in area of } \\
\text { scholarly } \\
\text { communication" }\end{array}$ & 18 \\
\hline $\begin{array}{l}\text { "Development \& } \\
\text { implementation of } \\
\text { institutional open } \\
\text { access policies" }\end{array}$ & 48 & $\begin{array}{l}\text { "Digital } \\
\text { object type \& } \\
\text { format" }\end{array}$ & 24 & & & $\begin{array}{l}\text { "Liaise with faculties } \\
\text { on CD \&instruction in } \\
\text { area of scholarly } \\
\text { communication" }\end{array}$ & 18 \\
\hline $\begin{array}{l}\text { "Legislative } \\
\text { environment" }\end{array}$ & 27 & $\begin{array}{l}\text { "e- } \\
\text { classification } \\
\& \\
\text { cataloguing } \\
\text { process" }\end{array}$ & 12 & & & & \\
\hline
\end{tabular}


Table 3. Emphasis Area

\begin{tabular}{|c|c|c|c|c|c|c|c|c|c|}
\hline $\begin{array}{l}\text { Institutional } \\
\text { Repository } \\
\text { Management }\end{array}$ & RF & $\begin{array}{l}\text { Publishing } \\
\text { Services }\end{array}$ & RF & $\begin{array}{l}\text { Copyright } \\
\text { Services }\end{array}$ & RF & $\begin{array}{l}\text { Data } \\
\text { manage } \\
\text { ment } \\
\text { Services }\end{array}$ & $\mathbf{R F}$ & $\begin{array}{l}\text { Assessment } \\
\text { and Impact } \\
\text { Matrices }\end{array}$ & RF \\
\hline $\begin{array}{l}\text { "Ability to collect, } \\
\text { store \& preserve } \\
\text { faculty, staff \& } \\
\text { student intellectual } \\
\text { output", }\end{array}$ & 100 & $\begin{array}{l}\text { "Knowledge } \\
\text { of and } \\
\text { experience } \\
\text { with the full } \\
\text { life cycle of } \\
\text { publishing", }\end{array}$ & 37 & $\begin{array}{l}\text { "Knowledg } \\
e \quad \text { of } \\
\text { pertinent } \\
\text { national } \\
\text { copyright } \\
\text { law" }\end{array}$ & 77 & $\begin{array}{l}\text { Knowled } \\
\text { ge on } \\
\text { Data } \\
\text { descripti } \\
\text { on \& } \\
\text { storage }\end{array}$ & 87 & $\begin{array}{l}\text { "Understandi } \\
\text { ng of } \\
\text { indicators of } \\
\text { research } \\
\text { impact, their } \\
\text { strengths \& } \\
\text { limitations" }\end{array}$ & 75 \\
\hline $\begin{array}{l}\text { "Knowledge of \& } \\
\text { ability to apply } \\
\text { publisher policies } \\
\text { on archiving" }\end{array}$ & 34 & $\begin{array}{l}\text { "Knowledge } \\
\& \text { experience } \\
\text { with minting } \\
\text { identifiers" }\end{array}$ & 18 & $\begin{array}{l}\text { "Awarenes } \\
s \text { of the } \\
\text { judicial } \\
\text { environmen } \\
t "\end{array}$ & 35 & $\begin{array}{l}\text { "Knowle } \\
\text { dge on } \\
\text { Data } \\
\text { managem } \\
\text { ent } \\
\text { planning } \\
\text { ", }\end{array}$ & 60 & $\begin{array}{l}\text { "Understandi } \\
\text { ng of } \\
\text { emerging } \\
\text { alternative } \\
\text { measures of } \\
\text { impact" }\end{array}$ & 42 \\
\hline $\begin{array}{l}\text { "Knowledge of \& } \\
\text { ability to apply } \\
\text { metadata } \\
\text { schemata" }\end{array}$ & 33 & $\begin{array}{l}\text { "Possess a } \\
\text { basic } \\
\text { knowledge of } \\
\text { relevant } \\
\text { metadata } \\
\text { schemata" }\end{array}$ & 40 & $\begin{array}{l}\text { "Understa } \\
\text { nding of } \\
\text { author's } \\
\text { rights", }\end{array}$ & 91 & $\begin{array}{l}\text { "Knowle } \\
\text { dge of \& } \\
\text { ability to } \\
\text { apply } \\
\text { funder } \\
\text { mandates } \\
\text { related to } \\
\text { data } \\
\text { storage, } \\
\text { access, \& } \\
\text { retention } \\
\text { " }\end{array}$ & 39 & $\begin{array}{l}\text { "Knowledge } \\
\text { of faculty } \\
\text { profile } \\
\text { systems \& } \\
\text { academic } \\
\text { social } \\
\text { networks" }\end{array}$ & 60 \\
\hline $\begin{array}{l}\text { "Knowledge of \& } \\
\text { experience with } \\
\text { repository } \\
\text { solutions" }\end{array}$ & 36 & $\begin{array}{l}\text { "Ability to } \\
\text { provide } \\
\text { technical } \\
\text { support on } \\
\text { publishing } \\
\text { services" }\end{array}$ & 68 & $\begin{array}{l}\text { "Ability in } \\
\text { performing } \\
\text { licensing } \\
\text { services" }\end{array}$ & 22 & $\begin{array}{l}\text { "Knowle } \\
\text { dge of \& } \\
\text { experienc } \\
e \quad \text { with } \\
\text { open } \\
\text { source } \\
\text { and } \\
\text { hosted } \\
\text { data } \\
\text { repositor } \\
y \\
\text { solutions } \\
\text { ", }\end{array}$ & 41 & $\begin{array}{l}\text { "Knowledge } \\
\text { of faculty } \\
\text { activity } \\
\text { reporting } \\
\text { systems" }\end{array}$ & 49 \\
\hline $\begin{array}{l}\text { "Ability to develop } \\
\text { policies" }\end{array}$ & 66 & $\begin{array}{l}\text { "Knowledge } \\
\& \text { ability to } \\
\text { perform } \\
\text { system } \\
\text { administratio } \\
n \quad \& \\
\text { programming }\end{array}$ & 26 & $\begin{array}{l}\text { "Ability in } \\
\text { handling } \\
\text { permission } \\
\text { requests" }\end{array}$ & 21 & $\begin{array}{l}\text { "Knowle } \\
\text { dge on } \\
\text { collection } \\
\text { developm } \\
\text { ent, } \\
\text { organizat } \\
\text { ion of, \& } \\
\text { access to } \\
\text { third } \\
\text { party } \\
\text { data } \\
\text { sets" }\end{array}$ & 64 & $\begin{array}{l}\text { "Ability to } \\
\text { assess } \\
\text { journal for } \\
\text { impact \& } \\
\text { evidence of } \\
\begin{array}{l}\text { publication } \\
\text { rigor" }\end{array}\end{array}$ & 66 \\
\hline $\begin{array}{l}\text { "Ability to } \\
\text { reporting statistics } \\
\text { in support of } \\
\text { outreach }\end{array}$ & 6 & $\begin{array}{l}\text { "Ability to } \\
\text { collect \& } \\
\text { disseminate } \\
\text { assessment }\end{array}$ & 70 & $\begin{array}{l}\text { "Knowledg } \\
e \quad \text { of } \\
\text { Campus } \\
\text { copyright }\end{array}$ & 57 & $\begin{array}{l}\text { "Knowle } \\
\text { dge of } \\
\text { data } \\
\text { mining }\end{array}$ & 25 & & \\
\hline
\end{tabular}




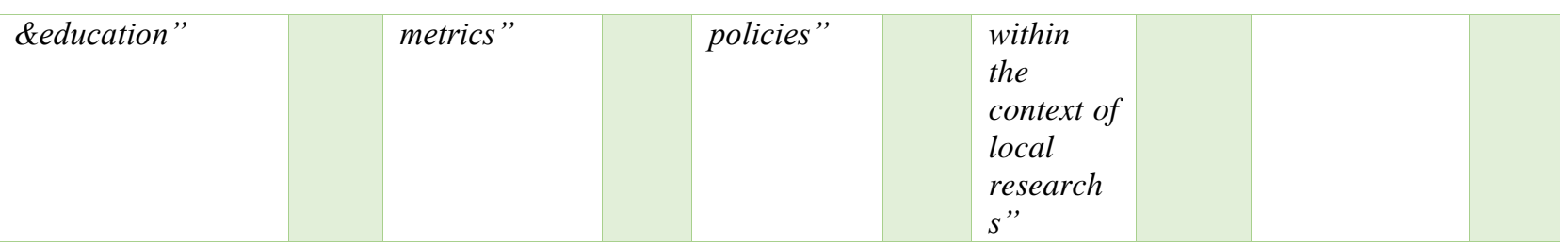

Responses frequency (RF) on institutional repository management in table 3 indicates that, $83.3 \%$ and $55 \%$ of the respondents can collect, store, and preserve research output and develop policies. As only 5\% can report statistics in support of outreach and education, less than $50 \%$ percent of the respondents have knowledge and ability to apply publisher policies on archiving, experience of repository solutions, and ability to apply metadata schemata.

Even though, this confirmed the findings of Okeji et al. (2019)that, librarians use repository platformsfor archiving their publications in Nigeria, it has corroborated the findings of Gbaje et al. (2017)that, there is no adequate knowledge on data curation and management activities between librarians in Nigeria, and also supported the findings of Adam and Kiran (2019)that, Librarians are lacking IT and professional skills for development and management of institutional repository.

It can be seen from table 3 that, $75.8 \%$ of the respondents understand the author's rights, and $64.1 \%$ have Knowledge of relevant national copyright law. However, less than $50 \%$ have the ability of handling permission requests, knowledge of campus copyright policies, awareness of the judicial environment, and ability to perform licensing services.

Responses on data management services were remarkable as $73.1 \%, 53.3 \%$ and $50 \%$ of the respondents have knowledge on data description and storage, collection development, organization ofand access to third-party data sets and knowledge on data management planning respectively. At the same time, $34.1 \%, 32.5 \%$, and $20.8 \%$ of the respondents have knowledge of and experience in open source and hosted data repository solutions, knowledge of and ability to apply funder mandates related to data storage, access and retention and knowledge of text and data mining, awareness of the licensing requirementsand application of copyright law respectively. The finding has shown incredible development in terms of data management services from the findings of Gbaje et al. (2017) which indicated that a low percentage of librarians had an understanding of data management activities in Nigeria.

From assessment and impact metrics, it can be realized that, Even though, only $35 \%$ and 40.83 of the respondents understand emerging alternative measures of research impact and knowledge of faculty activity reporting systems, $62.5 \%, 55 \%$ and $50 \%$ of the respondents understand the indicators of research impact, their strengths, and limitations, can assess journal for impact and evidence of publication rigor and have knowledge of faculty profile systems and academic social networks respectively. These findings established a significant level of awareness on assessment and impact metrics by librarians in Nigeria. Although the findings supports Gbaje et al. (2017) findings that, librarians lack knowledge on altimetry practices, it has shown improvement in terms of assessment of journal for impact and knowledge of faculty profile systems.

\section{Conclusion and Recommendation}

With $65 \%$ of respondents understand digital preservation and copyright, $74 \%$ have experience on repository platforms, $83.3 \%$ can collect, store, and preserve research output of the institutions and develop policies, $75.8 \%$ understand author's rights, $72.5 \%$, have knowledge on data description and storage, and $62.5 \%$, understand the indicators of research impact, their strengths, and limitations, it can be concluded that through awareness, skills, and competencies of librarians in Nigerian institutions is increasing accumulatively in the above-mentioned areas. However, there is need for improvement in the areas of metadata schema and standards, legislative and judicial publishing environments, technical skills such as e-cataloging and classification, liaising with faculty in area of scholarly communication, experience with repository solutions, application of mandates issued by research funders, faculty profiling systems and understanding of emerging alternative measures of research impacts.

The study recommends that, Nigerian institutions should send librarians for training on scholarly communication and repository management, with emphasis on data management, metrics assessment, repository policy, campus copyright, and license services. Similarly, Library schools should review their curriculums to include current trends on scholarly communication for librarians as well as set up a framework for the 
employment of repository and scholarly communication librarians. Finally, librarians should continue to attend training and workshops for capacity building on repository management and scholarly communication.

\section{References}

1. Adam, U. A., \& Kiran, K. (2019). Empirical Evidence of the Practice of Institutional Repository in Nigeria. Paper presented at the International Conference on Libraries, Information and Society (ICoLIS), Malacca, Malaysia.

2. Bergman, S. S. (2006). The scholarly communication movement: highlights and recent developments. Collection Building, 25(4), 108-128. doi:doi:10.1108/01604950610705989

3. Chawner, B., \& Oliver, G. (2013). A survey of New Zealand academic reference librarians: Current and future skills and competencies. Australian Academic \& Research Libraries, 44(1), 29-39.

4. Gbaje, E. S., Yani, S. D., \& Odigie, I. O. (2017). Assessing the Competencies and Skills of Academic Librarians in Nigeria for Scholarly Communication.

5. Hussain, A., Razak, H.A., Mkpojiogu, E.O.C. (2017). The perceived usability of automated testing tools for mobile applications. Journal of Engineering Science and Technology, 12 (Special Issue 4), pp. 89-97.

6. Hussain, A., Mkpojiogu, E.O.C., Abubakar, H., Hassan, H.M. (2017b). The usability evaluation of Mudah.my on mobile device. AIP Conference Proceedings, 1891, art. no. 020058.

7. Imeldawaty Gultom. 2020. CDMA Modulation for Communication System Environment using Frequency Hopping Spread Spectrum. IIRJET, V-6, I-1, EC-1 - EC-13

8. Lynch, C. A. (2003). Institutional repositories: essential infrastructure for scholarship in the digital age. portal: Libraries and the Academy, 3(2), 327-336.

9. Lynden, F. C. (2002). Scholarly communication report. Collection Management, 27(3-4), 95-102.

10. Marsh, R. M. (2015). The role of institutional repositories in developing the communication of scholarly research. OCLC Systems \& Services: International digital library perspectives, 31(4), 163 195. doi:doi:10.1108/OCLC-04-2014-0022

11. Nemati-Anaraki, L., \& Tavassoli-Farahi, M. (2018). Scholarly communication through institutional repositories: proposing a practical model. Collection Building, 37, 9-17. doi:10.1108/CC-01-2018002

12. Oguche, D. (2018). The state of institutional repositories and scholarly communication in Nigeria. Global Knowledge Memory and Communication, 67(1-2), 19-33. doi:10.1108/gkmc-04-2017-0033

13. Okeji, C. C., Eze, M. E., \& Chibueze, N. M. (2019). Awareness and use of self-archiving options among academic librarians in Nigerian universities. Global Knowledge, Memory and Communication, 68(1/2), 2-16.

14. Rodriguez, J. E. (2015). Scholarly communications competencies: open access training for librarians. New library world, 116(7/8), 397-405.

15. Saha, N. C., Sharma, A. K., \& Meichieo, K. (2008). Institutional repositories and skills requirements, a new horizon to preserve the intellectual output: An Indian perspective.

16. Sanjeeva, M., \& Powdwal, S. (2018). Skills and Competencies for Scholarly Communication: An Indian Perspective.

17. Van Westrienen, G., \& Lynch, C. A. (2005). Academic institutional repositories. D-lib Magazine, 11(9), 1082-9873.

18. Wesolek, A., Thomas, W., Dresselhaus, A., Fielding, J., Simser, C., \& Sutton, S. \& Appleton, B.(2017). NASIG Core Competencies for Scholarly Communication Librarians. In.

19. Zhong, J., \& Jiang, S. (2016). Institutional Repositories in Chinese Open Access Development: Status, Progress, and Challenges. Journal of Academic Librarianship, 42, 739-744. doi:10.1016/j.acalib.2016.06.015 